\author{
I E A Institute of \\ YK Business Administration \\ 页下 \\ Karachi \\ Leadership and Ideas for Tomorrow
}

Article 4

Volume 14 Issue 1

January-June 2019

\section{Business Review}

$1-1-2019$

\title{
Earnings response coefficient as a determinant of dividend policy: Testing free cash flow theory on non-financial dividend paying firms in the Pakistan Stock Exchange
}

Hamid Ullah

Islamia College, Peshawar, Pakistan

Anjum Ihsan

Islamia College, Peshawar, Pakistan

Follow this and additional works at: https://ir.iba.edu.pk/businessreview

Part of the Finance Commons, Management Sciences and Quantitative Methods Commons, and the Marketing Commons

\section{c) (i)}

This work is licensed under a Creative Commons Attribution 4.0 International License.

\section{Recommended Citation}

Ullah, H., \& Ihsan, A. (2019). Earnings response coefficient as a determinant of dividend policy: Testing free cash flow theory on non-financial dividend paying firms in the Pakistan Stock Exchange. Business Review, 14(1), 53-67. Retrieved from https://doi.org/10.54784/1990-6587.1024 


\title{
Earnings Response Coefficient as a determinant of dividend policy: Testing Free Cash Flow Theory on non-financial dividend paying firms in the Pakistan Stock Exchange
}

\author{
Hamid Ullah • Anjum Ihsan
}

\begin{abstract}
This study tests Jensen's free cash flow theory which states that managers overinvest retained earnings in negative NPV projects. A data set of 238 firms listed on the Pakistan Stock Exchange for the period 1999 to 2016 is used. The results of the panel regression model show a significant positive association of the earnings response coefficient and dividend payout ratio, which supports the free cash flow theory in listed Pakistani firms. Moreover, the imposition of the capital gains tax and the financial crisis has further strengthened the positive relationship between ERC and dividend payout ratio.
\end{abstract}

Keywords Free cash flow $\cdot$ Dividend payout - Capital gains tax · Pakistani firms.

\section{Introduction}

The existing literature documents a number of determinants of Earnings Response Coefficient (ERC) including beta (Collins and Kothari 1989; Biddle and Seow 1991; Easton and Zmijewski 1989; Biddle and Seow 1991; Hasanzade et al 2014; Zakaria and Daud 2013; Hakimpoor 2017), firm size (Easton and Zmijewski 1989; Mashayekhi and Aghel 2016), growth (Collins and Kothari 1989; Hasanzade et al 2014; Hakimpoor 2017), earnings growth (Yu and He 2013; Mashayekhi and Aghel 2016) and earnings persistence (Collins and Kothari 1989; Biddle and Seow 1991; Dhaliwal and Reynolds 1994).

Dividend is an important part of stock return and its payment conveys a signal to investors in the market that the company is adhering to sound corporate governance (Jo and Pan 2009). The pioneering work on dividend can be traced

Hamid Ullah

Islamia College, Peshawar-Pakistan

E-mail: hamidullah@icp.edu.pk

Anjum Ihsan

Islamia College, Peshawar-Pakistan 
to Miller and Modigliani (1961) who asserted dividend irrelevance with the argument that these are the future earnings and investment risk which affects the firm value. Corresponding to this, Jensen (1986) put forward the free cash flow hypothesis which advocates that companies overinvest free cash flow (cash left after all positive NPV projects are undertaken) in negative NPV projects rather than distributing these funds to the shareholders in the form of dividends. This is done by the management to escape the associated monitoring in case when funds are raised from capital markets resulting in agency costs. Kallapur (1994) tested the Jensen (1986) free cash flow theory and examined the influence of dividend payout on the earnings response coefficient. He found a positive and significant effect of the dividend ratio on the firms' earnings response coefficient. Furthermore, he also supported the free cash flow hypothesis by concluding that returns on retained earnings are less than the market's required rate of returns.

Before this, Lintner (1956) noted that firms have a tendency to cut dividend payments as investors sometimes interpret it as poor performance and drive down share prices. In line with this Bhattacharya (1979) and then Miller and Rock (1985) hinted that the dividend announcement communicates the firm's future prospects which can increase or decrease the share prices. This implies that dividend may affect the earnings-return relationship or the Earnings Response Coefficient (ERC). This study is therefore conducted to investigate the dividend payout ratio as a determinant of ERC and to test the free cash flow hypothesis as to whether the companies invest their free cash flows in projects with negative NPV or otherwise.

The pertinent studies conducted in Pakistan on earnings behaviour include one undertaken by Haider et al (2012) who investigated the relationship between dividend policy and earnings management targeting the listed companies using dividend payout ratio as a proxy of dividend policy and discretionary accrual as a proxy of earnings management. Their results depicted a very weak negative impact of earnings management on dividend policy. Moreover, earnings management was noted not to be done for the sake of dividend announcement but to get benefits from the companies' profit.

Very few studies have been undertaken with regard to ERC. Raza et al (2017) based on a study conducted on companies listed on the Pakistan Stock Exchange identified that controlling for the four established factors, audit quality was found significantly related with ERC. These four factors were also identified as important determinants of ERC in another study by Raza et al (2018) which was also undertaken on Pakistani companies. Their results also indicated that when the said four factors were controlled, board size was also found an important proxy which affects the ERC. The above studies did not investigate or identify dividend payout ratio as the determinant of ERC.

Therefore, this study aims to fill the underlying gap by examining the effect of dividend payout on earnings response coefficient following the testing mechanism of Kallapur (1994). However, this study is different from Kallapur (1994) in the sense that he has conducted his study in developed countries, which are entirely different in institutional settings as compared to transition economies like Pakistan. Additionally, we also test the effect of the capital gains tax and financial crisis on the relationship between dividend payout and ERC. 


\section{Literature review}

Lang and Litzenberger (1989) tested the free cash flow signalling and overinvestment by examining the effect of the dividend announcement on stock prices. They found that the average return of firms with less than unity Tobin's Q ratio (a proxy of overinvestment) was significantly high in comparison to those firms for which this ratio was greater than unity.

Based on a study conducted on Australian companies Flint et al (2010) found dividend payout ratio as one of the predictors of future earnings growth. Their results also indicated that the relationship between payout ratio and earnings growth is not dependent on simple mean reversion in earnings. They also found no evidence of free cash flow hypotheses and cash flow signalling to explain the payout ratio-earnings growth relationship. However, their study was limited as they did not take into account share repurchases into the calculation of payout ratio owing to data availability. Besides, the study also assumed linear trend in earnings growth which may be inconsistent with other studies like Fama and French (2000) and Grullon et al (2005) who viewed linearity as an incorrect assumption. Thus factoring in the non-linear effect into the underlying dividend payout-earnings relationship may provide more informative results. Kallapur (1994) tested the free cash flow theory by examining the effect of dividend payout on the earnings response coefficients. He found that dividend ratio has a positive significant effect on the firms' earnings response coefficient. Moreover, he also found that returns on retained earnings are less than the market's required rate of returns.

Zakaria et al (2012) documented that psychological factors contribute to share price changes. In this aspect, they investigated the investors' reaction to the dividends based on a study conducted on Malaysian companies where in significant influence of dividend payout ratio on share price volatility was noted with greater corresponding effect for large size companies. However, dividend yield, earnings volatility and investment growth were found insignificantly affecting the changes in share prices whereas leverage negatively affected the share price movement. However, their study was limited in scope as it targeted only the listed material and construction companies and not all the listed companies. Besides, there was also a methodological limitation as they used least squares regression model which explained only 43.43 percent variation in share price volatility.

Farooq et al (2018b) undertook a study on the firms from Middle East and North Africa (MENA) region. They documented that the reported earnings informativeness measure in terms of earnings and return relationship is dependent on the dividend payout ratio. Their argument asserted that increase in dividend decreases the agency conflicts and in turn reduces agency problem which leads to more truthful disclosure of information by the firms thereby making the reported earnings more credible. Farooq et al (2018a) also conducted another study on firms from the MENA region. Their results illustrated high dividend payout ratio positively affects the Earnings response coefficient (ERC).

Business Review: (2019) 14(1):53-67 


\section{Research design and methodology}

This section discusses the data collection, research model and computation and definition of variables.

\subsection{Sample size and data collection}

The sample of the study includes all those firms listed on the Pakistan Stock Exchange that have declared cash dividend from 1999 to 2017. The total number of such non financial firms is 238 , which have consistently declared dividends and have dividend data for at least 4 years. Furthermore, share prices and other financial data of firms also available for the sample period are included in the sample for analysis.

\subsection{Baseline regression model}

To test the effect of dividend payout ratio on the firm's earning response coefficient this study has adopted the research model of Kallapur (1994) with minor modifications. The control variables include earnings persistence, the riskiness of firm, firm size and firm growth.

$$
\begin{aligned}
\text { ERC }_{i t}=\alpha+\beta \text { Div } & +\beta \text { Size }_{i t}+\beta \text { Epersist }_{i t} \\
& +\beta \text { Growt }_{i t}+\beta \text { beta }_{i t}+\beta \text { industry }_{t}+\beta \text { year }_{i}+\mu_{i t}
\end{aligned}
$$

3.3 Variables definitions

\subsubsection{Earnings Response Coefficient}

This study has used Warfield et al., (1995) and Gabrielsen et al., (2002) to estimate the value of the Earnings response coefficient.

$$
R E T_{t}=\alpha+\beta\left(E P S / P t_{i}\right) t+\mu_{t}
$$

where RET stands for the 12 month stock returns starting from March to April for each fiscal year starting from January to December. ${ }^{1} E P S$ represents earnings per share of a firm in the year $t$ deflated by share price at the beginning of the year. Furthermore, for the robustness of the results and to control for the market factor the KSE-100 index is used for computing ERC by following Kallapur (1994).

\footnotetext{
1 The study also used data from January to December for computation of ERC used in different regression models however, the results were similar to the ERC computed using data from April to March each year.
} 


\subsubsection{Dividend payout}

The study used Lintner (1956) model to estimate the dividend payout which is measured by the following equation. The coefficient of EPS is used as the payout ratio. The model shows that a change in EPS will bring $\beta_{2}$ times change in the current year dividend which in turns brings about a change in the coming year dividend.

$$
\Delta D P S_{t}=\alpha+\beta_{1} D P S_{t-1}+\beta_{2} E P S_{t}+\mu_{t}
$$

where $\triangle D P S$ represents change in dividend per share, $E P S$ represents earnings per share and $\mu$ is the error term.

\subsubsection{Riskiness (beta)}

Earnings riskiness is estimated through the market model used in the studies of Collins and Kothari (1989) and Kallapur (1994) by using daily returns and market returns of KSE-100 index for each firm each year. Furthermore, Collins and Kothari (1989) suggested a negative relationship between earnings response coefficient and riskiness of earnings. ${ }^{2}$

\subsubsection{Earnings persistence}

Earnings persistence is represented by return on assets and is computed through accounting net income divided by total assets. Kallapur (1994) argued that return on assets is a better measure of earnings persistency as an increase in earnings due to reinvestment or uses of additional finance will not affect stock returns if the rate of return on additional investment equals to the rate of returns on shares.

\subsubsection{Firm growth}

In this study, firm growth is measured by the market to book value of a firm. Firms with more growth opportunities are expected to have more future earnings. Collins and Kothari (1989) suggested that the value of the earning s response coefficient is more for growth firms than non-growth firms. Therefore, this study is expected to have a positive relationship with firm growth (Easton and Zmijewski 1989).

\subsubsection{Firm size}

Firm size is measured by the log of total assets. The study includes firm size as an explanatory variable as the recent research studies suggested that in emerging economies firms vary in size which is expected to have a marginal effect on the

\footnotetext{
2 In the computation of beta, stock returns and market returns were also checked for stationarity of the returns through ADF test and no serial correlation was found in stock returns and index returns in year-firm return.
} 
H. Ullah, A. Ihsan

earnings response coefficient. Furthermore, large firms' earnings and dividends are assumed to be more stable relative to small firms. Therefore, firm size is included as a control variable in the main model of Kallapur (1994).

\section{Results and discussion}

This section presents and discusses results of descriptive statistics, correlation and the different regression models.

\subsection{Descriptive statistics}

Table 1 shows the results of the descriptive statistics of the dependent and independent variables of regression. The results show that on average firms have an earnings response coefficient of 0.142, dividend 12.152, EPS 8.964, earnings persistence 0.076 , beta of 1.027 , growth of 1.375 , size of 15.50 and leverage of 0.117 . Potential outliers have been removed from the data and the value of the standard deviation shows that the data follows a normal distribution.

Table 1: Descriptive statistics

\begin{tabular}{lccccc}
\hline Variable & Obs & Mean & Std.Dev. & Min & Max \\
\hline ERC & 4462 & 0.142 & 0.245 & -0.774 & 1.143 \\
Dividend & 4354 & 12.152 & 7.771 & 0.936 & 21.091 \\
EPS & 4432 & 8.964 & 6.133 & -1.848 & 18.025 \\
Earning persistence & 4432 & 0.076 & 0.059 & -0.016 & 0.316 \\
Beta & 4432 & 1.027 & 0.483 & -0.107 & 1.95 \\
Growth & 4432 & 1.375 & 1.015 & 0.151 & 3.955 \\
Size & 4432 & 15.5 & 1.369 & 13.135 & 19.492 \\
Leverage & 4432 & 0.117 & 0.266 & 0.321 & 0.858 \\
\hline
\end{tabular}

Table 1 shows descriptive statistics of ERC which are computed according to Warfield et al., (1995) and Gabrielsen et al., (2002), dividend is computed using Lintner (1956), EPS is computed as net income divided by outstanding shares, earnings persistence is measured by net income divided by total assets, beta is measured through CAPM by utilizing daily stock returns, growth is measured in terms of market value to book value, size is measured in terms of log of total assets and leverage is measured in terms of debts divided equity.

\subsubsection{Mean comparison test on the basis of dividend payments}

The group means comparison test is performed in order to check the assumption that dividend payments may vary with the firm's financial characteristics such as size of firm, growth, leverage, EPS and earnings persistence. For this purpose, a categorical variable is computed with a value equal to 1 for those firms where dividend payments are more than the median dividend, otherwise 0 . The results of the group mean comparison tests are reported in table 2 showing the mean differences of different variables on the basis of dividend payments with their 
respective t-calculated and P-calculated values.

The result of the group means comparison test shows a statically significant

Table 2: Mean comparison test on the basis of mean dividend payments

\begin{tabular}{lccc}
\hline Variables & Mean diff & T-value & P-value \\
\hline EPS & -3.875 & -5.354 & 0.000 \\
Firm growth & -0.644 & -5.646 & 0.000 \\
Size & -0.521 & -3.012 & 0.001 \\
Beta & -0.274 & -3.016 & 0.000 \\
Leverage & 0.740 & 5.564 & 0.000 \\
Earnings persistence & -0.027 & -3.630 & 0.000 \\
\hline
\end{tabular}

Table 2 shows the results of mean comparisons test where grouping variable is dividend with value of 1 if it is more than mean otherwise 0, EPS is computed as net income divided by outstanding shares, earning persistence is measured by net income divided by total assets, beta is measured through CAPM by utilizing daily stock returns, growth is measured in terms of market value to book value, size is measured in terms of log of total assets and leverage is measured in terms of debts divided equity.

difference in the financial characteristics between firms paying above and below the median dividends. Thus, it can be concluded that firms with a large size, more growth opportunities and leverage, with high EPS and earning persistence are different for high or low dividend paying firms.

\subsection{Pearson Correlation}

The results of the correlation table show that there is no intense correlation between any two variables that can cause multicollinearity. Furthermore, there exists a positive association of earnings response coefficient with the dividend payout ratio, earnings per share, earnings persistence, growth and size of the firm. However, there is a negative association of earnings response coefficient with the riskiness of the firm and leverage.

These results suggest that large firms with more growth opportunities, high expected earnings per share, more earnings persistence and paying more dividends are positively perceived by investors, measured in terms of ERC. However, a firm with more riskiness and use of high-level leverage is negatively perceived by the firm investors reflected by ERC. The positive association of the dividend is in line with the free cash flow hypothesis.

\subsection{Regression of ERC, dividend payout and control variables}

To test the hypothesis that whether listed firms in Pakistan suffer from the free cash flow problem this study follows the association of ERC and dividend payout established by the Kallapur (1994) with the implication that in case of free 
H. Ullah, A. Ihsan

Table 3: Matrix of Pearson Correlation

\begin{tabular}{lcccccccc}
\hline Variables & 1 & 2 & 3 & 4 & 5 & 6 & 7 & 8 \\
\hline ERC & 1.000 & & & & & & & \\
Dividend & 0.611 & 1.000 & & & & & & \\
EPS & 0.137 & 0.389 & 1.000 & & & & & \\
Earning persistence & 0.131 & 0.320 & 0.426 & 1.000 & & & & \\
Beta & -0.106 & -0.053 & -0.029 & 0.249 & 1.000 & & & \\
Growth & 0.097 & -0.368 & 0.109 & 0.356 & 0.160 & 1.000 & & \\
Size & 0.068 & 0.129 & 0.124 & 0.041 & 0.364 & 0.131 & 1.000 & \\
Leverage & -0.033 & -0.020 & -0.103 & -0.078 & 0.081 & -0.023 & 0.191 & 1.000 \\
\hline
\end{tabular}

Table 3 shows Pearson Correlation results, where ERC is computed according to Warfield et al., (1995) and Gabrielsen et al., (2002), dividend is computed using Lintner (1956), EPS is computed as net income divided by outstanding shares, earnings persistence is measured by net income divided by total assets, beta is measured through CAPM by utilizing daily stock returns, growth is measured in terms of market value to book value, size is measured in terms of $\log$ of total assets and leverage is measured in terms of debts divided equity.

cash flow problem, investors will prefer dividend over reinvestment in wasteful projects.

Table 4 shows results of stepwise regressions of earnings response coefficient and dividend payout with other conventional determinants of earnings response coefficient. The lower part of the table shows industry and year dummies in order to capture the variation in ERC due to time and industry specific factors. Moreover, $R^{2}$ and adjusted $R^{2}$ are also reported to check the incremental explanatory power of each model with the inclusion of each new variable in different models and found significant improvement in the adjusted $R^{2}$ with the inclusion of more variables in the main model. The Hausman test statistics are given at the end which suggest that fixed effect modeling is more preferable than random effect modeling in all specifications.

The results reported in table 4 show that dividend payout has a positive and significant relationship with the earninsg response which is in line with the free cash flow hypothesis of Jensen (1986). In this vein, a positive and significant association of the dividend payout with ERC is attributed to the fact that those managers overinvest the retained earnings in such projects that have relatively lower return rate than the market, which attract the rational investors to prefer dividends rather than wasteful retention (Kallapur 1994). Moreover, the free cash flow problem may arise when the managers reinvest the profits rather than paying it out to the shareholders. This behavior of the manager is likely to have autonomy on firm cash that would be lost in case of dividend payments. Moreover, this reinvestment of profits may increase the firm size and salaries and generate rewards for the managers.

The coefficients of earnings per share and firm size have significant and positive relationships with the earnings response coefficient as shown by their respective models and supported with the studies of Collins and Kothari (1989), and Easton and Zmijewski (1989). The results show that beta has a negative and significant relationship with earnings response coefficient, while leverage has a negative but insignificant relationship with the earnings response coefficient in all models as expected (Collins and Kothari 1989; Easton and Zmijewski 1989). 
However, growth is found to have a positive but insignificant relationship with earnings response coefficient.

The overall results suggest the presences of the free cash flow problem in

Table 4: Regression results of ERC, dividend and control variables

\begin{tabular}{|c|c|c|c|c|c|c|c|}
\hline Variables & (1) & (2) & (3) & (4) & (5) & (6) & (7) \\
\hline & ERC & ERC & $\mathrm{ERC}$ & ERC & ERC & ERC & $\mathrm{ERC}$ \\
\hline \multirow[t]{2}{*}{ Dividend } & $0.040^{* * *}$ & $0.035^{* * *}$ & $0.031 * * *$ & $0.029^{* *}$ & $0.028^{* *}$ & $0.025^{* *}$ & $0.040^{*}$ \\
\hline & -0.002 & -0.004 & -0.07 & -0.014 & -0.014 & -0.012 & -0.011 \\
\hline \multirow{2}{*}{ EPS } & & $0.007^{* *}$ & $0.005^{* *}$ & $0.006^{* *}$ & $0.006^{* * *}$ & $0.006^{* *}$ & $0.006^{* *}$ \\
\hline & & -0.003 & -0.002 & -0.003 & -0.002 & -0.003 & -0.003 \\
\hline \multirow{2}{*}{$\begin{array}{l}\text { Earning } \\
\text { persistence }\end{array}$} & & & 0.145 & 0.324 & 0.316 & 0.441 & 0.431 \\
\hline & & & -0.193 & -0.25 & -0.165 & -0.423 & -0.221 \\
\hline \multirow[t]{2}{*}{ Beta } & & & & $-0.064^{* *}$ & $-0.071^{*}$ & $-0.073^{* *}$ & $-0.073^{* *}$ \\
\hline & & & & -0.031 & -0.031 & -0.036 & -0.036 \\
\hline \multirow[t]{2}{*}{ Growth } & & & & & 0.022 & 0.022 & 0.022 \\
\hline & & & & & -0.015 & -0.015 & -0.015 \\
\hline \multirow[t]{2}{*}{ Size } & & & & & & $0.050^{* * *}$ & $0.061^{* * *}$ \\
\hline & & & & & & -0.01 & -0.011 \\
\hline \multirow[t]{2}{*}{ Leverage } & & & & & & & -0.001 \\
\hline & & & & & & & -0.002 \\
\hline \multirow[t]{2}{*}{ Cons } & $0.046^{*}$ & 0.011 & -0.001 & -0.027 & -0.039 & -0.111 & -0.124 \\
\hline & -0.025 & -0.023 & -0.023 & -0.029 & -0.031 & -0.154 & -0.158 \\
\hline $\begin{array}{l}\text { Industry } \\
\text { dummy }\end{array}$ & Yes & Yes & Yes & Yes & Yes & Yes & Yes \\
\hline $\begin{array}{l}\text { Years } \\
\text { dummy }\end{array}$ & Yes & Yes & Yes & Yes & Yes & Yes & Yes \\
\hline Obs. & 4432 & 4432 & 4432 & 4432 & 4432 & 4432 & 4432 \\
\hline$R^{2}$ & 0.002 & 0.016 & 0.034 & 0.036 & 0.036 & 0.037 & 0.038 \\
\hline $\begin{array}{l}\text { Hausman } \\
\text { test }\end{array}$ & $9.00(0.00)$ & $7.10(0.00)$ & $6.50(0.00)$ & $9.70(0.00)$ & $8.60(0.00)$ & $7.50(0.00)$ & $9.12(0.00)$ \\
\hline
\end{tabular}

Table 4 shows stepwise regression results where dependent variable is ERC which is computed according to Warfield et al., (1995) and Gabrielsen et al., (2002), dividend is computed by estimating Lintner (1956), EPS is computed as net income divided by outstanding shares, earning persistence is measured by net income divided by total assets, beta is measured through CAPM by utilizing daily stock returns, growth is measured in terms of market value to book value, Size is measured in terms of log of total assets and leverage is measured in terms of debts divided equity. Standard errors are in parenthesis ${ }^{* * *} \mathrm{p}<0.01,{ }^{* *} \mathrm{p}<0.05,{ }^{*} \mathrm{p}<0.1$.

listed firms of Pakistan. Furthermore, the stepwise regression showed that the dividend payout is an important variable that can better explain the investor's perception measured in terms of earning response coefficient. Moreover, this ERC and dividend payout relationship is a better proxy for the earnings persistence as it is managed by the firm managers based on their superior information relating to persistence of earnings, therefore higher earnings persistence leads to high ERC and also motivate the managers to set a higher dividend payout ratio (Kallapur 1994). Table 5 shows the results of the assumption that financial crisis and capital gain tax have significant effect on the association of dividend payments and ERC. The results in table 6 support the baseline regressions results reported in table 4. Further inclusion of the capital gain tax and financial crisis have a significant and negative relationship with the ERC. Now to test 
H. Ullah, A. Ihsan

Table 5: Regression results of interaction variables with dividend payout

\begin{tabular}{|c|c|c|c|c|c|c|}
\hline & 1 & 2 & 3 & 4 & 5 & 6 \\
\hline & ERC & $\mathrm{ERC}$ & $\mathrm{ERC}$ & ERC & ERC & ERC \\
\hline \multirow[t]{2}{*}{ Dividend } & $0.030^{* *}$ & $0.029 *$ & $0.028^{* *}$ & 0.04 & 0.04 & 0.04 \\
\hline & -0.014 & -0.015 & -0.02 & -0.004 & -0.004 & -0.004 \\
\hline \multirow[t]{2}{*}{ EPS } & $0.006^{*}$ & $0.0059^{*}$ & $0.016^{* * *}$ & 0.005 & $0.006^{* *}$ & $0.0059 *$ \\
\hline & -0.003 & -0.003 & -0.005 & -0.004 & -0.003 & -0.003 \\
\hline \multirow{2}{*}{$\begin{array}{l}\text { Earning } \\
\text { persistence }\end{array}$} & 0.235 & $0.251^{*}$ & 0.19 & $0.853^{* *}$ & 0.267 & 0.267 \\
\hline & -0.224 & -0.125 & -0.229 & -0.419 & -0.225 & -0.225 \\
\hline \multirow[t]{2}{*}{ Beta } & $-0.033^{* *}$ & $-0.032 *$ & -0.038 & $-0.029 *$ & $-0.038^{* *}$ & $-0.058^{*}$ \\
\hline & -0.016 & -0.017 & -0.037 & -0.015 & -0.019 & -0.039 \\
\hline \multirow[t]{2}{*}{ Growth } & 0.022 & 0.031 & $0.029 *$ & 0.021 & 0.022 & 0.022 \\
\hline & -0.015 & -0.026 & -0.015 & -0.015 & -0.015 & -0.015 \\
\hline \multirow[t]{2}{*}{ Size } & $0.070^{* * *}$ & $0.061^{*}$ & $0.051 * * *$ & $0.071 * * *$ & $0.085^{* *}$ & $0.083^{*}$ \\
\hline & -0.02 & -0.031 & -0.011 & -0.01 & -0.04 & -0.042 \\
\hline \multirow[t]{2}{*}{ Leverage } & -0.001 & -0.002 & -0.003 & -0.002 & -0.001 & -0.003 \\
\hline & -0.005 & -0.009 & -0.009 & -0.008 & -0.008 & -0.008 \\
\hline Div $_{\text {size }}$ & $\begin{array}{c}0.005^{* * *} \\
-0.001\end{array}$ & & & & & \\
\hline Div ${ }_{\text {growth }}$ & & $\begin{array}{c}0.001 \\
-0.001\end{array}$ & & & & \\
\hline$D_{E P S}$ & & & $\begin{array}{c}0.001^{* * *} \\
0\end{array}$ & & & \\
\hline \multicolumn{2}{|c|}{ Div Earningpersistence $_{\text {E }}$} & & & $\begin{array}{c}0.043^{* *} \\
-0.021\end{array}$ & & \\
\hline Div $_{\text {Beta }}$ & & & & & $\begin{array}{l}-0.003 \\
-0.003\end{array}$ & \\
\hline \multicolumn{2}{|l|}{ Div $_{\text {Leverage }}$} & & & & & $\begin{array}{c}-0.006^{* *} \\
-0.003\end{array}$ \\
\hline Cons & $\begin{array}{c}0.561 \\
-0.301\end{array}$ & $\begin{array}{c}0.546^{* * *} \\
-0.162\end{array}$ & $\begin{array}{c}0.531^{* * *} \\
-0156\end{array}$ & $\begin{array}{c}0.736^{* * * *} \\
-0.152\end{array}$ & $\begin{array}{c}0.281 \\
-0.145\end{array}$ & $0.509^{*}$ \\
\hline Industry & Yes & Yes & Yes & Yes & Yes & Yes \\
\hline Year & Yes & Yes & Yes & Yes & Yes & Yes \\
\hline Obs. & 4432 & 4432 & 4432 & 4432 & 4432 & 4432 \\
\hline$R^{2}$ & 0.039 & 0.043 & 0.039 & 0.038 & 0.04 & 0.04 \\
\hline $\begin{array}{l}\text { Hausman } \\
\text { test }\end{array}$ & $9.10(0.00)$ & $8.10(0.00)$ & $9.60(0.00)$ & $7.51(0.00)$ & $8.70(0.00)$ & $8.51(0.00)$ \\
\hline
\end{tabular}

Table 5 shows regression results where dependent variable is ERC which is computed by Warfield et al., (1995) and Gabrielsen et al., (2002), dividend is computed using Lintner (1956), EPS is computed as net income divided by outstanding shares, earning persistence is measured by net income divided by total assets, beta is measured through CAPM by utilizing daily stock returns, growth is measured in terms of market value to book value, size is measured in terms of $\log$ of total assets and leverage is measured in terms of debts divided equity. Interaction terms include interaction of dividend coefficient with size, EPS, Leverage, Earning persistence, growth and beta in different models. Standard errors are in parenthesis $* * * \mathrm{p}<0.01,{ }^{* *} \mathrm{p}<0.05$, $* \mathrm{p}<0.1$.

that either the introduction of capital gain tax and financial crisis change the dividend payment behavior of the firm. The results show a significant and positive relationship of ERC and the interaction of dividend with capital gain tax and financial crisis. These results suggest that imposition of capital gain tax creates more attraction for investors to prefer dividend over capital gain and leads to a positive effect on the association of dividend and ERC (Hasanzade et al 2014). Furthermore, in times of financial crisis firms pay more dividends 
Earnings response coefficient...

Table 6: Regression results of dividend and ERC in financial crisis and capital gains tax

\begin{tabular}{|c|c|c|c|c|}
\hline \multirow[t]{2}{*}{ Variables } & (1) & (2) & (3) & (4) \\
\hline & ERC & ERC & $\mathrm{ERC}$ & ERC \\
\hline \multirow[t]{2}{*}{ Dividend } & $0.031^{* *}$ & $0.046 * * *$ & $0.040^{*}$ & $0.051^{*}$ \\
\hline & -0.014 & -0.019 & -0.02 & -0.021 \\
\hline \multirow[t]{2}{*}{ EPS } & $0.005^{*}$ & $0.006^{*}$ & $0.005^{*}$ & $0.006^{*}$ \\
\hline & -0.002 & -0.003 & -0.002 & -0.003 \\
\hline \multirow{2}{*}{$\begin{array}{l}\text { Earning } \\
\text { tence }\end{array}$} & 0.04 & 0.079 & 0.061 & 0.005 \\
\hline & -0.269 & -0.281 & -0.264 & -0.262 \\
\hline \multirow[t]{2}{*}{ Beta } & $-0.047^{*}$ & $-0.041^{*}$ & -0.043 & $-0.038 * *$ \\
\hline & -0.023 & -0.021 & -0.036 & -0.018 \\
\hline \multirow[t]{2}{*}{ Growth } & 0.021 & 0.022 & 0.021 & 0.02 \\
\hline & -0.016 & -0.015 & -0.015 & -0.014 \\
\hline \multirow[t]{2}{*}{ Size } & $0.071 * * *$ & 0.011 & $0.026^{* *}$ & $0.091^{* * *}$ \\
\hline & -0.011 & -0.011 & -0.012 & -0.011 \\
\hline \multirow[t]{2}{*}{ Leverage } & -0.002 & -0.002 & -0.002 & -0.002 \\
\hline & -0.003 & -0.002 & -0.002 & -0.002 \\
\hline \multirow[t]{2}{*}{$\begin{array}{l}\text { Capital } \\
\operatorname{tax}\end{array}$} & $-0.427^{* *}$ & & & \\
\hline & -0.212 & & & \\
\hline Div Capitalgainstax & & $\begin{array}{l}0.005^{*} \\
-0.002\end{array}$ & & \\
\hline Financial crisis & & & $\begin{array}{c}-0.007^{*} \\
-0.003\end{array}$ & \\
\hline Div Financialcrisis & & & & $\begin{array}{c}0.007^{* * *} \\
-0.002\end{array}$ \\
\hline \multirow[t]{2}{*}{ Cons } & 0.292 & 0.18 & 0.106 & 0.14 \\
\hline & -0.345 & -0.172 & -0.17 & -0.169 \\
\hline Industry & Yes & Yes & Yes & Yes \\
\hline Year & Yes & Yes & Yes & Yes \\
\hline Obs. & 4437 & 4437 & 4437 & 4437 \\
\hline$R^{2}$ & 0.102 & 0.199 & 0.147 & 0.266 \\
\hline Hausman test & $15.78(0.00)$ & $12.18(0.00)$ & $11.17(0.00)$ & $17.18(0.00)$ \\
\hline
\end{tabular}

Table 6 shows regression results where dependent variable is ERC which is computed by Warfield et al., (1995) and Gabrielsen et al., (2002), dividend is computed using Lintner (1956), EPS is computed as net income divided by outstanding shares, earning persistence is measured by net income divided by total assets, beta is measured through CAPM by utilizing daily stock returns, growth is measured in terms of market value to book value, size is measured in terms of log of total assets and leverage is measured in terms of debts divided equity. An interactions term includes interaction of dividend with financial crisis and capital gains tax. Standard errors are in parenthesis $* * * \mathrm{p}<0.01$, ** $\mathrm{p}<0.05,{ }^{*} \mathrm{p}<0.1$.

in order to restore the confidence of investors and has a significant positive effect on the ERC (Ullah et al 2012). Thus, our results of association of dividend payouts and ERC are robust for the capital gain tax and financial crisis. ${ }^{3}$

\footnotetext{
3 "An information story that is consistent with the positive association between ERCs and payout ratios is that firms with lower returns on retentions pay out a smaller fraction of their earnings because managers know that their future cash requirements will be higher. Since this information effect depends on a free cash flow argument, it does not contradict the free cash flow theory."
} 
H. Ullah, A. Ihsan

Table 7: Regression results of ERC, dividend and control variables

\begin{tabular}{|c|c|c|c|c|c|c|c|}
\hline & 1 & 2 & 3 & 4 & 5 & 6 & 7 \\
\hline & ERC & ERC & $\mathrm{ERC}$ & $\mathrm{ERC}$ & ERC & $\mathrm{ERC}$ & $\mathrm{ERC}$ \\
\hline \multirow[t]{2}{*}{ Dividend } & $0.060 * * *$ & $0.045^{* * *}$ & $0.041^{* * *}$ & $0.037 * *$ & $0.031 * *$ & $0.025 * *$ & $0.022 * *$ \\
\hline & -0.004 & -0.005 & -0.05 & -0.016 & -0.015 & -0.011 & -0.011 \\
\hline \multirow[t]{2}{*}{ EPS } & & $0.006^{* *}$ & $0.006^{* *}$ & $0.007^{* *}$ & $0.007 * * *$ & $0.007 * *$ & $0.006^{* *}$ \\
\hline & & -0.003 & -0.003 & -0.003 & -0.002 & -0.003 & -0.003 \\
\hline \multirow{2}{*}{$\begin{array}{l}\text { Earning per- } \\
\text { sistence }\end{array}$} & & & 0.135 & $0.314^{* *}$ & 0.212 & $0.441^{* *}$ & $0.431^{* *}$ \\
\hline & & & -0.193 & -0.15 & -0.165 & -0.221 & -0.221 \\
\hline \multirow[t]{2}{*}{ Beta } & & & & $-0.044^{* *}$ & $-0.081^{*}$ & $-0.083^{* *}$ & $-0.071^{* *}$ \\
\hline & & & & -0.021 & -0.041 & -0.031 & -0.036 \\
\hline \multirow[t]{2}{*}{ Growth } & & & & & $0.022 * *$ & $0.021 * *$ & 0.022 \\
\hline & & & & & -0.01 & -0.01 & -0.015 \\
\hline \multirow[t]{2}{*}{ Size } & & & & & & $0.050 * * *$ & $0.061 * * *$ \\
\hline & & & & & & -0.01 & -0.011 \\
\hline \multirow[t]{2}{*}{ Leverage } & & & & & & & -0.001 \\
\hline & & & & & & & -0.002 \\
\hline \multirow[t]{2}{*}{ Cons } & $0.049^{*}$ & 0.012 & -0.011 & -0.017 & -0.019 & -0.011 & -0.224 \\
\hline & -0.025 & -0.013 & -0.013 & -0.019 & -0.021 & -0.054 & -0.258 \\
\hline $\begin{array}{l}\text { Industry } \\
\text { dummy }\end{array}$ & Yes & Yes & Yes & Yes & Yes & Yes & Yes \\
\hline Years dummy & Yes & Yes & Yes & Yes & Yes & Yes & Yes \\
\hline Obs. & 4432 & 4432 & 4432 & 4432 & 4432 & 4432 & 4432 \\
\hline$R^{2}$ & 0.002 & 0.016 & 0.034 & 0.036 & 0.037 & 0.039 & 0.041 \\
\hline Hausman test & $12.00(0.00)$ & $9.10(0.00)$ & $11.00(0.00)$ & $9.70(0.00)$ & $9.10(0.00)$ & $11.10(0.00)$ & $8.22(0.00)$ \\
\hline
\end{tabular}

Table 7 shows stepwise regression results where dependent variable is ERC which is computed according to Kallapur (1994), dividend is computed by estimating Lintner (1956), EPS is computed as net income divided by outstanding shares, earnings persistence is measured by net income divided by total assets, beta is measured through CAPM by utilizing daily stock returns, growth is measured in terms of market value to book value, size is measured in terms of log of total assets and leverage is measured in terms of debts divided equity. Standard errors are in parenthesis ${ }^{* * *} \mathrm{p}<0.01,{ }^{* *} \mathrm{p}<0.05,{ }^{*} \mathrm{p}<0.1$

\subsection{Robustness of results}

The extant literature shows that dividend payments may vary with the riskiness of a firm, size and use of leverage, high historical earnings persistency and growth rate. Therefore, this study used an interactive dummy of dividend payout with all these variables that may affect the positive association of dividend and ERC. Furthermore, the capital gains tax may have a significant effect on this association which can be further investigated by including a dummy variable for the year in which capital gains tax is imposed on capital gain in this section to check the incremental effect of the taxes on the dividend and ERC association. There was a financial crisis in 2007 and 2008 therefore in order to explore that this study uses a dummy variable with a value of 1 for the crisis years and 0 otherwise.

Table 5 show results of the baseline regression model with additional variables and the interaction of dividend payout with each of the explanatory variables stepwise. The lower part of the table shows industry and year dummies, $R^{2}$ and adjusted $R^{2}$. The Hausman test statistics are given at the end which suggests that fixed effect modeling is more preferable than random effect modeling 
in all specifications as expected. Table 5 shows the results of the regression models with interaction variables, the results are supportive of the baseline model and almost all the coefficient and their respective significance remains the same.

The dividend payout and ERC association remain positive and significant in all specifications; however, the significance varies with the introduction of interaction terms in different models. The coefficients of the interaction variables such as size, earnings per share and earnings persistence have a significant positive effect on the earnings response coefficient. These results suggest that a large firm with more dividend payments improves the positive effects of dividend on ERC. Similarly, high earnings per share and earnings persistence increases the probability of dividend payments which further strengthens the association of dividend payout and ERC. The coefficients of beta and leverage interactions with dividend payout are negative but significant only in case of leverage. These results suggest the increase in leverage reduces the expectations of dividend payments which further weaken the association of dividend payout and ERC.

Following Kallapur (1994) we compute ERC by including the market returns on KSE-100 index in order to control for the market factor and re-estimated the baseline models as represented in table 7 . The regression results show that the effect of dividend payout on ERC remains the same as of the baseline models and consistent with the free cash flow hypothesis of Jensen (1986) and supports the study of Kallapur (1994). The coefficients of earnings per share and firm size are found to have significant and positive relationships with ERC whereas, beta has a negative and significant relationship with ERC but growth is found to have a positive and significant effect on ERC. The overall results remain the same with the baseline models estimations.

\section{Conclusion}

This study tests the free cash flow theory of Jensen (1986) which states that managers overinvest retained earnings in negative NPV projects. The free cash flow problem refers to a situation where managers reinvest profits rather than paying it to the shareholders. This study is based on the implication that earnings response coefficient is positively associated with the dividend payout ratio. For this purpose, the study used a large data set of 238 firms listed firm in the Pakistan Stock Exchange for the period 1999 to 2017.

The results of the panel regression models show that there exists a significant and positive association of the earnings response coefficient and dividend payout ratio, which supports the free cash flow theory in Pakistani listed firms. Thus, firms do invest their retained earnings in order to avoid the monitoring associated with raising capital from the external market. Moreover, the imposition of the capital gains tax and the financial crisis have further strengthened the positive association of ERC and dividend payout ratio. 


\section{References}

Bhattacharya S (1979) Imperfect information, dividend policy, and the bird in the hand fallacy. Bell journal of economics 10(1):259-270

Biddle GC, Seow GS (1991) The estimation and determinants of associations between returns and earnings: Evidence from cross-industry comparisons. Journal of Accounting, Auditing \& Finance 6(2):183-232

Collins DW, Kothari S (1989) An analysis of intertemporal and cross-sectional determinants of earnings response coefficients. Journal of accounting and economics 11(2-3):143-181

Dhaliwal DS, Reynolds SS (1994) The effect of the default risk of debt on the earnings response coefficient. Accounting Review pp 412-419

Easton PD, Zmijewski ME (1989) Cross-sectional variation in the stock market response to accounting earnings announcements. Journal of Accounting and economics 11(2-3):117141

Fama EF, French KR (2000) Forecasting profitability and earnings. The Journal of Business $73(2): 161-175$

Farooq O, Shehata N, Nathan S (2018a) Dividend policy and informativeness of reported earnings: Evidence from the mena region. International Review of Finance 18(1):113-121

Farooq O, Shehata NF, Nathan S (2018b) Earnings response coefficient in the mena region. Applied Economics Letters 25(16):1147-1152

Flint A, Tan A, Tian GG (2010) Predicting future earnings growth: A test of the dividend payout ratio in the australian market. The International Journal of Business and Finance Research 4(2):43-58

Grullon G, Michaely R, Benartzi S, Thaler RH (2005) Dividend changes do not signal changes in future profitability. The Journal of Business 78(5):1659-1682

Haider J, Ali A, Sadiq T (2012) Earning management and dividend policy: Empirical evidence from pakistani listed companies. European Journal of Business and Management 4(1):8390

Hakimpoor N (2017) Investigating the determinants of earnings response coefficient: A case study of tehran stock exchange

Hasanzade M, Darabi R, Mahfoozi G (2014) Factors affecting the earnings response coefficient: An empirical study for iran. European Online Journal of Natural and Social Sciences: Proceedings 2(3 (s)):pp-2551

Jensen MC (1986) Agency costs of free cash flow, corporate finance, and takeovers. The American economic review 76(2):323-329

Jo H, Pan C (2009) Why are firms with entrenched managers more likely to pay dividends? Review of Accounting and Finance 8(1):87-116

Kallapur S (1994) Dividend payout ratios as determinants of earnings response coefficients: A test of the free cash flow theory. Journal of Accounting and economics 17(3):359-375

Lang LH, Litzenberger RH (1989) Dividend announcements: Cash flow signalling vs. free cash flow hypothesis? journal of Financial Economics 24(1):181-191

Lintner J (1956) Distribution of incomes of corporations among dividends, retained earnings, and taxes. The American Economic Review 46(2):97-113

Mashayekhi B, Aghel ZL (2016) A study on the determinants of earnings response coefficient in an emerging market. International Journal of Social, Behavioral, Educational, Economic, Business and Insustrial Engineering 10(7):2454-2457

Miller M, Modigliani F (1961) Dividend policy, growth, and the valuation of shares

Miller MH, Rock K (1985) Dividend policy under asymmetric information. The Journal of finance 40(4):1031-1051

Raza W, Ihsan A, Jan S (2017) Effect of big 4 on earning response coefficient: Evidence from pakistan. Journal of Managerial Sciences 11

Raza W, Ihsan A, Jan S, Ullah H (2018) Effect of board size on earning response coefficient (evidence from pakistan). Abasyn University Journal of Social Sciences

Ullah H, Fida A, Khan S (2012) The impact of ownership structure on dividend policy evidence from emerging markets kse-100 index pakistan. International Journal of Business and Social Science 3(9)

Yu Y, He Y (2013) Does the history of ex-ante abnormal earnings growth forecasts affect earnings response coefficient 
Zakaria NB, Daud D (2013) Does big 4 affect the earnings response coefficient (erc)? evidence from malaysia. Journal Of Modern Accounting and Auditing 9(9)

Zakaria Z, Muhammad J, Zulkifli AH (2012) The impact of dividend policy on the share price volatility: Malaysian construction and material companies. International Journal of Economics and Management Sciences 2(5):1-8 